\title{
NHậN XÉT MỘT SỐ ĐẠC ĐIỂM LÂM SÀNG, HİNH ẢNH CHỤP CĂT LỚP VI TÍNH VÀ TỔN THƯƠNG MÔ BỆNH HỌC SARCOMA NHẦY NGUYÊN PHÁT Ở PHỔI. NHÂN MỘT TRƯờNG HợP
}

\author{
Nguyễn Trưòng Giang*; Trần Ngoc Dũng* \\ Nguyê̂n Ngoc Trung*; Nguyê̂n Văn Nam*; Nguyến Thành Lề*
}

\section{TÓM TẮT:}

Thông báo một trường hợp hiếm gặp trên lâm sàng: sarcoma dạng nhầy ở phổi. Bệnh nhân nam, 30 tuổi, phát hiện một khối u phổi trái kích thước $4,5 \mathrm{~cm}$, có vỏ dày, ranh giới rõ. Khối u cấu trúc chủ yếu là mô đệm nhầy rộng lớn, ngăn cách nhiều ổ bởi các tế bào u hình thoi hoặc hình đa diện, có nhân nhỏ sắp xếp thành các dải hoặc hình lưới. Hình ảnh hóa mô miễn dịch, các tế bào khối u dương tính với vimentin và kháng nguyên biểu mô màng, nhưng âm tính với CK7, TTF-1, MUC1, CK20, CDX-2, MUC2.

Remark on clinical features, CT scan and pathology of primary pulmonary myxoid sarcoma. The first case was operated.

\section{SUMMARY}

Reported here is an extremely rare case of primary pulmonary myxoid sarcoma (PPMS). A 30-year-old man presented with a $4,5 \mathrm{~cm}$-sized pulmonary tumor surrounded by capsule-like fibrosis. This tumor focally showed endobronchial features, and consisted of reticular cords of oval, short spindle, or polygonal cells with swollen vesicular nuclei accompanied by an abundant myxoid stroma, closely resembling extraskeletal myxoid chondrosarcoma. Tumor cells were diffusely positive for vimentin and focally positive for epithelial membrane antigen, but were negative for CK7, TTF-1, MUC1, CK20, CDX-2, MUC2.

Key word: primary pulmonary myxoid sarcoma.

\section{1. ĐẠT VẤN ĐỀ}

Trên lâm sàng hầu hết các ung thư của tổ chức liên kết (sarcoma) gặp ở phổi là di căn ung thư. Sarcoma nguyên phát ở phồi là một bệnh lý rất hiếm gặp, chiếm tỷ lệ 1/500-550 so với ung thư biểu mô (carcinoma). Những sarcoma nguyên phát ở phổi thường là sarcoma mạch máu, sarcoma nội mô mạch máu dạng biểu bì, u nguyên bào xơ cơ dạng viêm hoặc sarcoma nội mạc. Sarcoma nhầy nguyên phát ở phổi (Primary pulmonary myxoid sarcomas: PPMS) với các đặc tính bệnh lý riêng biệt đã được Nicholson A.G và cộng sự mô tả những trường hợp đầu tiên vào năm 1999. Cho đến nay, mới chỉ có rất ít các trường hợp PPMS được đề cập tới trong y văn [2], [4], [5].
Đặc điểm mô học của sarcoma dạng nhầy ở phổi là một khối u với mô đệm nhầy rộng lớn, ngăn cách nhiều ổ bởi các tế bào u hình thoi hoặc hình đa diện, sắp xếp thành các dải hoặc hình lưới. Tuy nhiên, mặc dù đặc điểm mô học và các biến đổi di truyền của nó đã được biết đến, song đặc tính sinh học của nó vẫn chưa rõ ràng vì đây là một khối u rất hiếm mới được biết đến gần đây, cũng như thiếu các dấu ấn hóa mô miễn dịch đặc hiệu hơn vimentin. Một số tác giả cho rằng, sarcoma dạng nhầy ở phổi có thể được bắt nguồn từ tế bào trung mô nguyên thủy ở phổi với sự biệt hóa nguyên bào sợi hoặc nguyên bào xơ cơ.

Nhằm mục đích hiểu biết hơn về sarcoma nhầy ở phổi. Để bổ sung thêm những kinh nghiệm trong chẩn đoán, chúng tôi xin rút ra một số nhận xét về đặc điểm lâm sàng, cận lâm sàng và hình ảnh tổn thương mô bệnh học của sarcoma nhầy ở phổi nhân trường một hợp được phẫu thuật tại bệnh viện Quân y 103 năm 2015.

\section{KẾT QUẢ NGHIÊN CÚ̉ VÀ BÀN LUẬN}

- Bệnh nhân: Phạm Tuấn T -30 tuổi

- Ngày vào viện: 30/3/2015

- Ngày phẫu thuật: 08/04/2015

- Chẩn đoán trước mổ: U thùy trên phổi trái

- Tiền sử: Khỏe mạnh, không hút thuốc lá.

- Bệnh sử: Vô tình khám và phát hiện u phổi trái ngày 24/03/2014. Trước đó đôi khi có ho, đờm trắng, khản tiếng nhẹ. Có điều trị một đợt kháng sinh bệnh đỡ ít.

Ngày 31/03/2014, sinh thiết phổi hút tại khoa Lao và Bệnh phổi, bệnh viện quân y 103 , kết quả tế bào học là : tổ chức hoại tử (số tiêu bản F851). Điều trị bằng kháng sinh đường uống, long đờm. Các bác sỹ đã khuyên bệnh nhân nên phẫu thuật nhưng bệnh nhân xin ra viện về nhà điều trị.

Ngày 30/3/2015 vào lại khoa Phẫu thuật Lồng ngực - Tim mạch, với biểu hiện ho nhiều, đờm trắng.

* Bộ môn-Khoa Phẫu thuật lồng ngục-Tim mạch-Bệnh viện 103Học viện Quân Y

Ngườ chịu trách nhiệm khoa học: PGS.TS Nguyễn Trường Giang

Ngày nhận bài: 20/07/2015 - Ngày Cho Phép Đăng: 20/08/2015

Phản Biện Khoa họ: PGS.TS. Đặng Ngoc Hùng PGS.TS. Bùi Đúc Phú 
- Khám bệnh:

+ Thể trạng trung bình, cao $164 \mathrm{~cm}$. Nặng $62 \mathrm{~kg}$.

+ Khám thấy: Toàn thân có biểu hiện thiếu máu nhẹ, da niêm mạc hơi nhợt. Cơ quan hô hấp không phát hiện dấu hiệu bệnh lý, không có các biểu hiện của hội chứng cận $u$.

- Kết quả chụp cắt lớp vi tính lồng ngực:

+ 24/3/2014: Khối u thùy trên phổi trái, kích thước 27x29mm ngấm thuốc cản quang.

+ Tháng 9/2014: Khối u thùy trên phổi trái, kích thước u 30x32mm ngấm thuốc chậm, có bờ viền khối u rõ.

+ 30/3/2015: Khối u thùy trên phổi trái, kích thước $45 \times 53 \mathrm{~mm}$ tăng sinh mạch máu. Ngấm thuốc chậm. Bờ viền khối u rõ.

- Phẫu thuật cắt thùy trên phổi trái ngày 08/4/2015.

- Diễn biến trong và sau mổ thuận lợi.

- Kết quả mô bệnh học:

\section{+ Đại thể:}

Khối u kích thước lớn $5 \times 6 \mathrm{~cm}$, ranh giới rõ, nằm gọn trong thùy trên, sát rốn phổi, mặt cắt màu trắng hơi trong, xám nhạt.

\section{+Vi thế:}

Sinh thiết là tổ chức u với cấu trúc chủ yếu là mô đệm nhầy rộng lớn, ngăn cách nhiều ổ bởi các tế bào u hình thoi hoặc hình đa diện, có nhân nhỏ sắp xếp thành các dải hoặc hình lưới.

+ Hóa mô miễn dịch:

Vimentin Dương tính

CK7: Âm tính TTF-1 Âm tính MUC1: Âm tính

CK20: Âm tính CDX-2 Âm tính MUC2: Âm tính

+ Chẩn đoán giải phẫu bệnh lý: Sarcoma nhầy (Myxoid Sarcoma)

\section{1. Đặc điểm lâm sàng:}

Trong số 17 ca được công bố cho thấy: Sarcoma dạng nhầy ở phổi chủ yếu xảy ra ở người lớn với phạm vi độ tuổi rộng (26-67 tuổi), không có sự phân biệt về giới và tiền sử hút thuốc. Hầu hết các bệnh nhân có các triệu chứng do khối u chèn ép hoặc phát hiện u một cách ngẫu nhiên với kích thước biến đổi từ 1,5 đến $13 \mathrm{~cm}$.

Các tác giả Yoon Kyung Jeon, Kyung Chul Moon, Sung-Hye Park, Doo Hyun Chung nghiên cứu tất cả các trường hợp $\mathrm{u}$ phổi được cắt bỏ tại Bệnh viện Đại học quốc gia Seoul (Hàn quốc) từ năm 2000-2012 đã công bố 4 trường hợp sarcoma dạng nhầy ở phổi. Tuổi bệnh nhân là $26,49,54,65$, gồm 2 nam, 2 nữ, không có tiền sử hút thuốc, có 2 trường hợp có tiền sử lao phổi, 2 trường hợp có biểu hiện ho, cả 4 trường hợp có thiếu máu nhẹ.

Bệnh nhân của chúng tôi tuổi trẻ, 30 tuổi, tình cờ phát hiện khối u phổi, tuy nhiên vị trí u là thùy trên (các nghiên cứu khác gặp chủ yếu thùy dưới) phổi trái. Là khối u có kích thước lớn. Bệnh nhân cũng có tiền sử không hút thuốc lá và có thiếu máu nhẹ phù hợp với một sarcoma xơ nhầy nguyên phát ở phổi.

Như vậy có thể nhận thấy một số đặc điểm lâm sàng của sarcoma nhầy ở phổi trên bệnh nhân của chúng tôi cũng phù hợp với công bố của các tác giả trên thế giới. Các đặc điểm lâm sàng là thường gặp ở bệnh nhân tuổi trẻ, không liên quan đến tiền sử hút thuốc lá, diễn biến lâm sàng chậm, các triệu chứng mờ nhạt, không có các biểu hiện của các hội chứng cận u, ngoài ra có thể có biểu hiện thiếu máu nhẹ.

\section{2. Đặc điểm chụp cắt lớp vi tính lồng ngụ̣c:}

Nghiên cứu của các tác giả Yoon Kyung Jeon, Kyung Chul Moon, Sung-Hye Park, Doo Hyun Chung trên 4 trường hợp PPMS (Primary pulmonary myxoid Sarcoma) nhận thấy cả 4 trường hợp khối u nằm ở thùy dưới (2 trường hợp phổi phải và 2 trường hợp phổi trái). Kích thước $\mathrm{u}$ thường lớn từ $4-13 \mathrm{~cm}, 3$ trường hợp không có di căn hạch quanh phế quản. Thời gian sống thêm ngắn nhất là 19 tháng và dài nhất là 152 tháng. Một trường hợp xuất hiện lao hạch sau phẫu thuật 15 tháng và 1 trường hợp di căn phổi đối diện (phổi phải) sau 7 tháng.

Trên hình ảnh chụp cắt lớp vi tính lồng ngực bệnh nhân của chúng tôi là một khối u nằm sát trung tâm phổi trái, có bờ viền của lớp vỏ xơ rõ, ngấm thuốc cản quang kém. Kích thước khối u khá lớn 45x53mm. Theo dõi theo thời gian thấy kích thước khối u phát triển chậm.

Theo chúng tôi nhận thấy hình ảnh chụp cắt lớp vi tính của bệnh nhân hoàn toàn khác với các ung thư phế quản nguyên phát. Hình ảnh khối u nằm sát trung tâm phổi, kích thước khá lớn, tuy nhiên ranh giới rất rõ, có vỏ xơ dày và ngấm thuốc cản quang kém và chủ yếu ở vùng vỏ. Theo thời gian kich thước khối u tăng lên chậm.

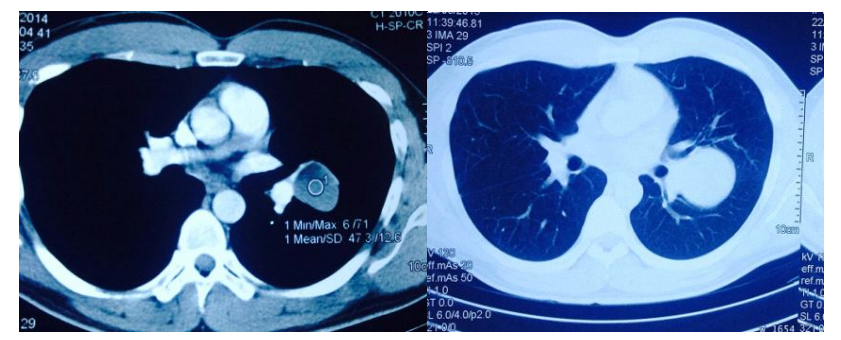

Hình 1: Hình ảnh chụp CT Scan phổi. 


\section{3. Đặc điểm tổn thương giải phẫu bệnh lý:}

Trong số 17 ca PPMS được công bố cho thấy các đặc tính mô học có sự chồng lấn với các khối u mô mềm dạng nhầy khác hoặc các khối u tuyến nước bọt, bao gồm sarcoma sụn nhầy ngoài xương (Extraskeletal myxoid chondrosarcoma - EMC), u cơ biểu mô, u nội mô mạch máu dạng biểu bì, và khối u nguyên bào xơ cơ dạng viêm (Inflammatory myofibroblastic tumor: IMT) $[1,3]$. Trong các IMT, các tế bào ung thư hình thoi được sắp xếp thành dải trong các bó hoặc xếp lớp với sự có mặt của các tế bào viêm trong mô đệm xơ và bộc lộ với các dấu ấn miễn dịch SMA và / hoặc desmin [1]. Các hình thái bắt chước PPMS mạnh nhất là $\mathrm{EMC}$, có phản ứng dương tính ổ với dấu ấn EMA và $\mathrm{S}-100[2,3]$.

Yoon Kyung Jeon, Kyung Chul Moon, Sung-Hye Park, Doo Hyun Chung nghiên cứu 4 trường hợp PPMS. Tất cả các trường hợp đã được làm xét nghiệm hóa mô miễn dịch, làm kỹ thuật lai tại chỗ (FISH), quan sát hình thái siêu cấu trúc trên kính hiển vi điện tử để xác định chẩn đoán sarcoma dạng nhầy ở phổi. Đặc điểm mô học: Cả 4 trường hợp u nằm cạnh phế quản, tính chất đa ổ. Có $3 / 4$ trường hợp xuất huyết trong $\mathrm{u}$ và không có hình ảnh hoại tử. Các tế bào không điển hình ít. Số lượng nhân chia ít từ 0-1 nhân chia/10 vi trường có độ phóng đại cao. Cả 4 trường hợp đều có sự xâm nhiễm của tương bào (plasmocyte).

Đặc điểm hóa mô miễn dịch: âm tính với hầu hết các dấu ấn biểu mô, thần kinh nội tiết và các dấu ấn liên kết ngoại trừ cả 4 trường hợp đều dương tính với vimentin.

Bệnh nhân của chúng tôicó các đặc điểm tổn thương giải phẫu bệnh lý như sau:

- Hình ảnh đại thể: Khối u kích thước lớn $5 \times 5,5 \times 6 \mathrm{~cm}$, ranh giới rõ, mặt cắt màu trắng hơi trong, xám nhạt.

- Vi thể: Tổ chức u với cấu trúc chủ yếu là mô đệm nhầy rộng lớn, ngăn cách nhiều ổ bởi các tế bào u hình thoi hoặc hình đa diện, có nhân nhỏ sắp xếp thành các dải hoặc hình lưới.

- Hóa mô miễn dịch: Dương tính với Vimentin, âm tính với $\mathrm{CK} 7, \mathrm{TTF}-1, \mathrm{MUC} 1, \mathrm{CK} 20, \mathrm{CDX}-2$ và MUC2.

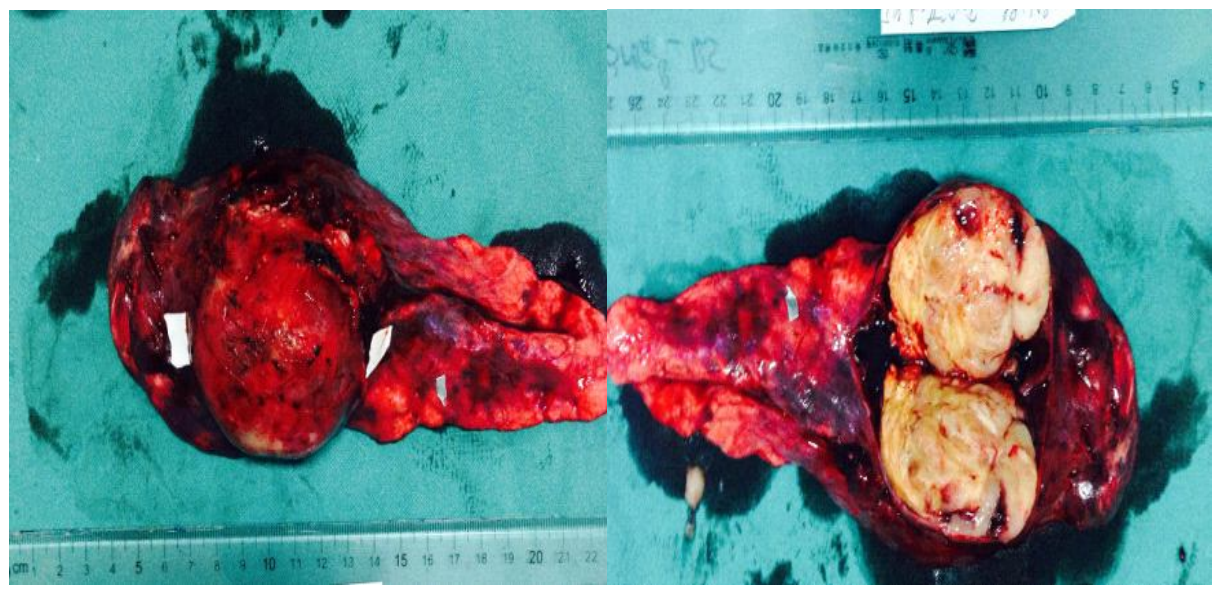

Hình 2: Hình ảnh đại thể khối u
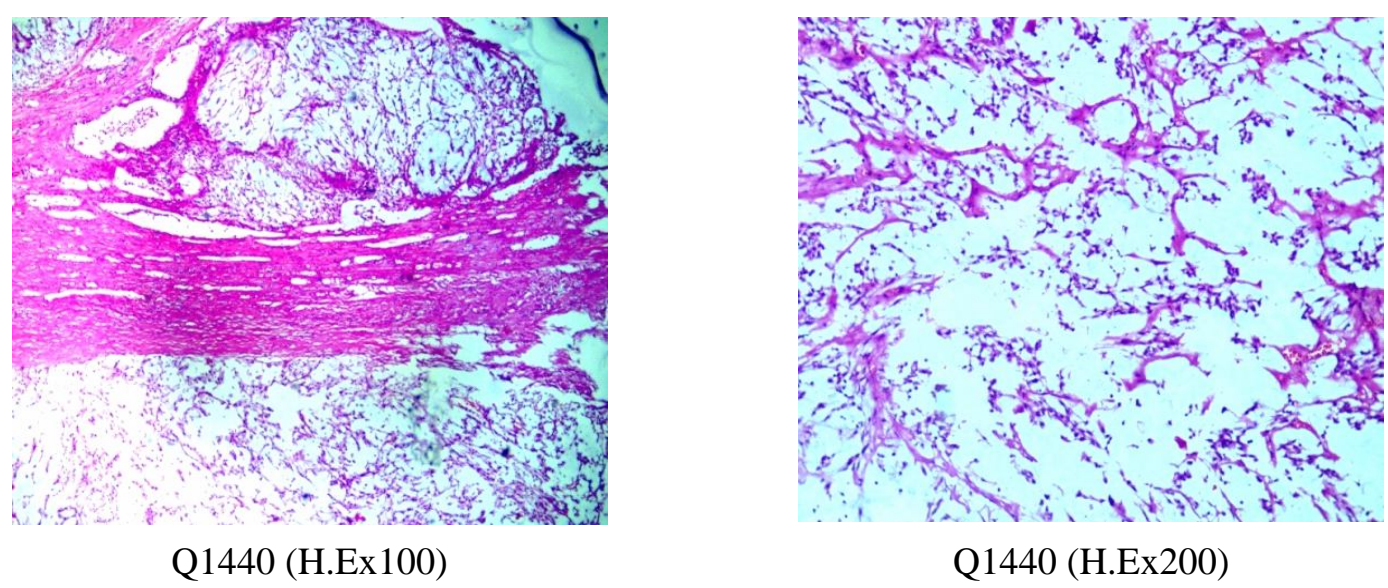

Hình 3: Hình ảnh nhuộm HE 

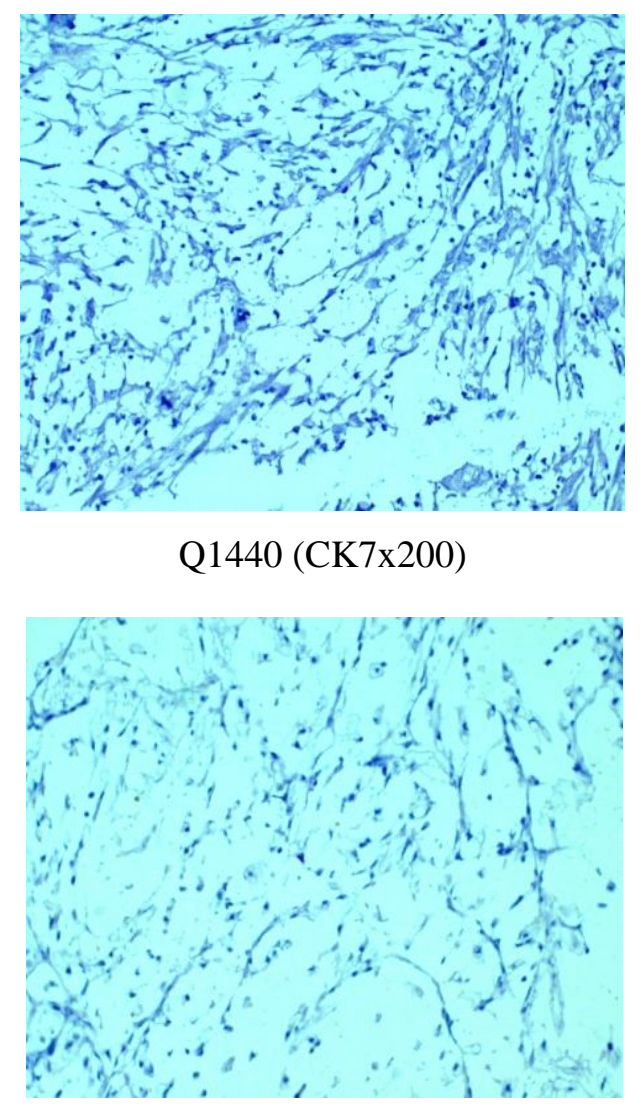

Q1440 (TTF1x200)

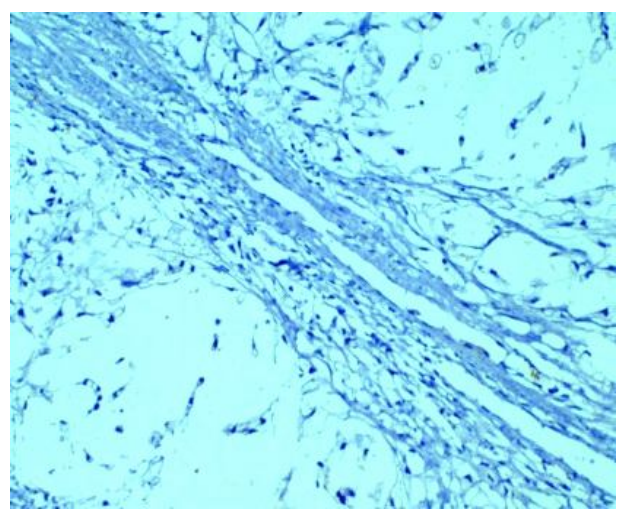

Q1440 (CK20x200)

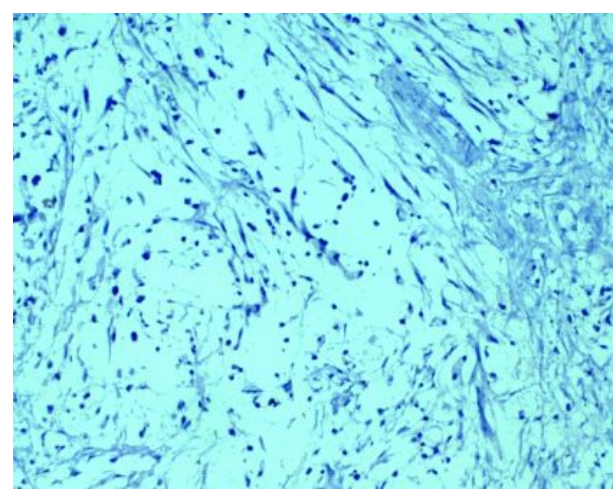

Q1440 (MUC1x200)

Hình 4: Hình ảnh nhuộm hóa mô miễn dịch

\section{KẾT LUẬN:}

Trường hợp bệnh nhân sarcoma nhày nguyên phát ở phổi được phát hiện tình cờ khối u thùy trên phổi trái và được phẫu thuật tháng 4/2015 tại Bệnh viện Quân y 103 là bệnh nhân trẻ tuổi, có các đặc tính lâm sàng, mô bệnh học và hóa mô miễn dịch phù hợp với các đặc tính của một sarcoma nhầy ở phổi theo như mô tả của y văn. Đây là bệnh lý rất hiếm gặp được phát hiện ở Việt Nam, cần được nghiên cứu thêm về di truyền, miễn dịch, và quan sát siêu cấu trúc để làm sáng tỏ thêm về chẩn đoán cũng như xác định thêm nguồn gốc tế bào của PPMS.

\section{TÀI LIỆU THAM KHẢO}

1. Fletcher CDM, Bridge JA, Hogendoorn PCW, Mertens $F$ (2013) WHO classification of tumours of soft tissue and bone, 4th edn. IARC, Lyon.

2. Goetz SP, Robinson RA, Landas SK (1992) Extraskeletal myxoid chondrosarcoma of the pleura. Report of a case clinically simulating mesothelioma.
Am J Clin Pathol 97(4):498-502.

3. Matsukuma S, Hisaoka M, Obara K, Kono T, Takeo H, Sato K, Hata Y (2012) Primary pulmonary myxoid sarcoma with EWSR1-CREB1 fusion, resembling extraskeletal myxoid chondrosarcoma: case report with a review of literature. Pathol Int 62(12):817-822. doi:10.1111/pin.12014.

4. Nicholson AG, Baandrup $U$, Florio $R$, Sheppard MN, Fisher C (1999) "Malignant myxoid endobronchial tumour: a report of two cases with a unique histological pattern". Histopathology 35(4):31

5. Yoon Kyung Jeon, Kyung Chul Moon, SungHye Park, Doo Hyun Chung (2014) "Primary pulmonary myxoid sarcomas with EWSR1-CREB1 translocation might originate from primitive peribronchial mesenchymal cells undergoing (myo)fibroblastic differentiation" Virchows Arch (2014) 465:453-461. 